\title{
EEN WOORD OVER DE BEVOORREGTING VAN DE LANDBOUWERS IN BELASTING-ZAKEN.
}

Het is voorwaar eene zware taak om een stelsel van belastingen, dat over het algemeen billijk werkt, uit te denken; zegge, over het algemeen, want bepalingen vast te stellen, die even billijk te acbten zijn in elk voorkomend geval en jegens ieder individu, is onmogelijk, en nog veel meer onmogelijk is het, bij de doorganude zucht om de algemeene lasten liever door de schouderen van anderen te doen torscben, een stelsel te beramen, dat iedereen bevredigt. Eindelijk is het in constitutionele staten, onder yewone omstandigheden althans vaak moeijelijk diep ingrijpende veranderingen tot stand te brengen. Het ligt niet in ons bestek om te onderzoeken, of ook dààr liefde tot de eigen beurs en de zucht tot bet behouden van de opgedragen lastgeving, de vrres voor de kiezers, in het spel zijn, man hoe dat zij, dat nuttige doortastende hervormingen soms door de vertegenwoordigende regeringsvorm belemmerd, vertraagd, of verhinderd worlen, zal wel niet veel tegensprak kunnen ontmoeten. Omgekeerd echter, om niet van de vele abdere zegeningen van dien regeringsrorm te spreken, oefent de vertegenwoordiging gelukkig denzelfden invloed uit op het kwale; ook de inveriug van hut kwale wordt door eene vertfgenwoorliging op weldaclige wịze bemoeijelijkt. En wordt men nu, overtuigd dat groote wijzigingeu in het algemeen belang allexins zijn an te raden, wel eens ongednldig, dat men tegenwerking ondervindt, juist daar, war men de meste onderstenning zonde verwachten, van de vertegenwoordiging, in de eerste plaats yeroupen on de belangen van het volk voor te staan, - won begrijpe, dat ann ieder stelsel bezwaren verbonden zijn en dat geen instellingen voluaakt, geen menschen onfeilbaar en volstrekt belangreloos kunnen rijn.

Vaar zij men het ouk al eens over het doel, dan merki men veelal ung een groot versehil op bij het beramen der middelen, die moeten strekken om dat doel te verwezenlijken. En dat verschil, ook tusschen limien the heluclfde doel voorstaan, zal somtijds veroorzaken, dat daarvan niets wordt verwezenlijkt. Daarom is het zoo nutlig, dat men 
het eerst over het beginsel cens zij. Is dat eenmaal vooraf vastuesteld, men zal het later meer genakkelijk eens worden over de middelen; in die meer ondergeschikte quaestien is toenadering meer rnogelijk, transactie niet alleen vergefelijk, maar zelfs meer of min aan te prijzen. Spreekt men danrentegen over beginsel en middel van uitwoering tevens, dan zullen bijzondere inzigten onmiddelijk op den voorgrond treden, de hartstogten gannde maken en veroorzaken, dat men zich in het gehee! niet kau verstaav. $\mathrm{Er}$ is nog eene andere reden tot bewandeling van den anngeprezen weg. Zonder nu juist te willen beweren, dat de meerderheid van onze invloedrijken beginselloos is, is het zeker ontegenzeggelijk, dat velen z:wak en weifelend zijn eu onder gewone omstandigheden tegen het nemen van fiksche en krachtige maatregelen opzien. Is dit nu af te kenren in elkeu mensch, in dubbele mate is het gevaarlijk in den staatsman en in hem, die op de algemeene zaak invloed witoefent. Die zwakke man zal, wanneer het beginsel is vastgesteld, en hem daardoor, als het ware een leiband is gegeven, niet meer zoo wankclbaar zijn in zijne schreden, hij zal daardoor kracht ontleenen ook tegeu eigen zwakheid en kloeker, dan anders zijn karakter medebrengt, over middelen, voorgedragen tot uitvoering van een bereids vistgesteld beginsel, heen stappen.

Ik wil trachten tot dat goede doel mede te werken en eenige beschonwingen mededeelen, ten betooge dat de landbouwer in Nederland over het algemeen te weinig tot de algemeene lasten bijdraagt.

Het grondwettelijk voorschrift, dat deze quaestie beheerscht is art. 172 , luidende "geene privilegien kunuen in het stuk van belastingen worlen verleend." Ofschoon men welligt zou kunnen meenen dat dit artikel meer geschreven is met het oog op den individu, zoo blijkt cvinwel viet dat de wetgever zulks tot den individu heeft willen beperken, het voorschrift is algemeen en, zal het doel treften, te voorkomeu dat de eeu to weinig en dardoor de andere te veel be. tale, zoo muet men nug veel meer tegen de bevocrregting pan eenen geheelen stand din tegen die ran, een enkel persoon wakea. Het is reeds hier boven gezegd, dat het onmogelijk is wetten te makeu en ze zoodinig tuetepassen, dai alles altijd naar volkomen billijkbeid en regtvaldrigheid toega en is dit ook al zeer te betreuren, de bevoorregting valn enkrle personen zal maar een klein verlies voor de schatkist zijin, de bevoorregting daarentegen van geheele standen veroorzaakt de derving van zeer aauzienlijke inkomsien voor de schatkist en des te meer moet natuurlijk door anderen worden opgebragt.

De begunstiging, ja bevoorregting van den stand der landbouwers, veehouders, warmoezeniers, bewerkers van groeven en mijnen, is gegrond 
op het physiocratisch systeem, waaraan wij zeker de beschermende regten, die vroeger ten opzigte van den landbouw golden, te danken of liever te wijten hebben gehad. Dat systeem wordt gelukkig meer en meer als verouderd aangemerkt doch, telt het al weinig of geen voorstanders meer, wij zijn daarom nog niet verlost van alle wetten onder dat systeem tot stand gekomen, schoon missehien ieder ze afkeurt.

Ten bewijze dat de landbouwende stand niet bevoorregt wordt, beroept men zich souns op de grondbelasiing en de regten van overgang als ook door de landbouwers gedragen. Naar wij meenen, is dat beroep echter ten onregte: immers, deze regten worden betaald door den eigenaar of kooper, niet door den gebruiker, en zijn beide hoedanigheden vereenigd, men betralt dan in de eerste, niet in de laatste betrekking. De groudbelasting is, zij ook al de wezenlijke huurwaarde over het algemeen vrij wat hooger dan de kadastrale, aanzienlijk. De voorbeelden zijn niet zeldzaam dat meu aan grond-eu polderlasten betaalt 15,20. ja mecrdere pet. van zijn werkelijk inkomen. Ik erken niettemin de bevoegdheid om, wanneer de staat grootere offers noorlig heeft, de groudbclasting te verhoogen, malar eerst dan wanneer men het privilegie heeft doen ophouden, dat thans ten behoeve van het roerend kapitaal bestaat. Sommigen zeggen, dat de meerdere grondbelasting door den gebruiker zoude worlen betaald, daar de eigenaar ook daarop, bij de vaststelling van den pachtprijs zoude letten. Ware dat zoo, niets zoude gemakkelijker zijn, dan de grondbelisting te verhoogen, doch ik ontkeu tell stellizste dat het zoo is $\left(^{*}\right)$. De eigenaar kan geenszins eigenmagtig den pachtprijs bepalen en waar groote mededinging, niet ontstaande door, of afhankelijk van het bedrag der grondbelasting, hem een prijs heeft doen bedingen boven de wezenlijke waarde, zal die prijs maar tijdelijk, niet voortdurend zijn.

De verhooging van de grondbelasting is daarentegen ongetwijfeld van registreekschen invloed op de koopwaarde; ieder financier zal toch vau de inkomsten de lasten aftrekken $\left(^{*}\right)$ en het zuiver bedrag kapitaliseren; verhooging der groudbelasting brengt alzoo noodwendig met zich vermiıdering in kapitaal-waarde, dus verlies van rijkdom. Uit dat oogpunt is zij, eveu als de regten van overgang bij verkoop, - en deze vooral niet, daar zij zeker niet uit de inkomsten betaald, maar van het kapital genomen worden, - minder goed te keuren. Schoon nu elke belasting op het kapitaal geene onvoorwaardelijke afkeuring verclient, (men denke aan bet successieregt, o. i. een der billijkste belastingen, )

(*) Zie waschrift iler redactie. 
moet men daarmerle viterst omzigtig zijn, zich vergenorgen met het ei en, voor het duurzaam genot daarvan, de hen in het leven laten.

Zoo de gebjuiker ran den grond als zoodanig niet betault in de grondbelasting en de regten van den overgang, zeggen wij thans nog een enkel woord over onze registratie en zegelwetien.

Begunstiging van den landbouw heeft den wetgever der wet van 16 Innij 1832 indertijd geleid tot de vermindering van de regten bij openbaren verkoop van veldvruchten en hout. In werkelijkheid echter zijn daarmede de openbare ambtenaren belast met de verkoopingen begunsliggl. En dat men geene bedoeling had die te begunstigen, blijkt in de andere bestaande wetten op het zegel en de registratie, waar de onderhandsehe akten van verhuring aan een veel lager tarief dan die voor de notarissen verleden, zijn onderworpen. Waar men ambtenaren benoemt, moest men er prijs op stellen, dat van luun ministerie gebruik gemaakt werd, docls de fiscus heeft dikwijls, met of zonder opzet, den onderhandsehen vorm begunstigd.

Langdurige pachten ziju voordeelig èn voor den gebruiker èn voor den grond, er wordt dan ook gewoonlijk een hoogere prijs gegeven, de wetgever intusschen en dat nog wel in een tijd dat hij bepaald begunstiging van den landbouw wenschte, onderwerpt die uitgiften aan zeer booge regten, vrij wat aanzienlijker dan bij gewone huur. Over de wet van 6 Junij 1840, bepalende vrijdommen van lasten bij landontginningen en landverbeteringen, heb ik reeds bij eene andere gelegenbeid gesproken en angetoond, boe de eerlijke man tijdelijken, de smokkelaar voortdurenden vrijdom geviet.

$\mathrm{Nu}$ wijzen wij er op, dat al die bepalingen in vetten zijn vervat, dat is, zijn tot stand gebragt met gemeen overleg van de Statengeneraal. In naam hebben wij eene constitutie sinds 1815 , in wezenlijkheid zeker niet voor 1848. Zelfstandige en onafbankelijke leden die niet blindelings goedkeurden wat hun voorgelegd werd, beschouwde men als gevaarlijke liedeu, als revolutionnairen!

En nu het patentregt. Hoezetr ik niet wil geacht worden het gronddenkbeeld van belasting op de uitoefening vau een of ander bedrijf in het afgetrokkene goed te keuren, zal, nu zij helaas al zoo lang bestaat, welligt meer geraden zijn dat middel aan te vullen en te verbeteren dan het op te heffen; de meeste bedrijven zijn aan dat middel onderworpen, werkbazen en fabrijkanten betalen ook roor bunne knechts, maar de laudbouwer is geheel vrijgesteld.

Ook in de wetten op de personele belasting ondervindi hij groote begunstiging: zijne schuren en stallen zijn geheel vrij van belusting, de huurwaarde is gesteld op een zeer lang cijfer; voor deuren en ven- 
sters betaalt hij weinig, het verschuldigde deswege wisselt af man de bevolking, van $44-77$ cent in hooflsom, eene groote bevoorregting van hel platte land. Ook in den 3en gromlsing, le haardsteden, is de plattelands-bewoner zeer begunst.jgd. Het bedrag regeit zich ten dize. niet naar de bevolking, maar naar het getal haardsteden, liet begint met $f 0.35$ en klimt tot $f 5$ het stuk. Daar de levenswijze ten platten lande een minder getal schoorsteencu vordert (de ovens zijn vrijgesteld), ligt ook danin eene bevoorregting van het platteland.

De regering koestert den wensch daaraan een einde te maken en drangt bij het ingediende ontwerp op het personeel voor, om voor elke deur of venster onverschillig te doen betalen $f 0,68$, voor elken schoorsteen, onverschillig het getal $f 4$. Ik juich de beweegreden der regering op zich zelf toe, doch mijne zienswijze over het voorgestelde bewijst weder, hoe wenschelijk het is, dat men eerst beginselen vaststelle, eer men gaat spreken over de middelen, die naar mijne meening althans, vooral wat de voordragt op den zen grondslag betreft, moeten nopen tot af'stemming. Welligt biedt zich nog wel eens nader de gelegenheid aan om mijne denkbeelden daaromtrent te ontwikkelen.

De belasting op het mobilair regelt zich of naar de huurwaarde, die, zoo als men weel, ten platten lande vrij lang bekend staat, of naar schatting. In het eerste geval is het platteland altijd aanzienlijk begunstigd en ook bij de bepnling van de belasting op de tweede wijze ineerendeels, daar over het algemeun de leveuswijzc te platten lande veel eenvoudiger is dan in de steden.

Ook in den $5^{\text {den }}$ grondslag ondervindt de laulbouwer groote bevoorregting, zijne arbeiders zijn geheel vrij, voor zijne dienstboden betaalt bij naar een niet opklimmeud, aamienlijk verminderd tarief.

$\mathrm{Bij}$ den $6^{\text {den }}$ grondslag is het niet auders, de paarden gebezigd voor het bedrijf, ja zelf's voor het genoegen, als men zich geene luxe of bijzonder gemak veroorlooft, zijn geheel vrij of worden, zoo de rijtuigen of banken veerkrachigg zijn onderstcund, althans naar een vrij wat lager tarief aangeslagen.

$\mathrm{Bij}$ het vourgedragen ontwerp op het personeel wil de regering de beide laatstgenoemde grondslagen aun de gemeenten afstaan; doet zich de invloed van onze landbouwers in de volkssertegenwoudiging al krachtig gelden, zoodat er weinig gevaar bestaat, dat zij daar onbillijk zouden worlen behandeld, die afstand, geljjk hij is roorgesteld eu waar vrij wat meer tegen te zeggen is, zal in vole gemeenten, war de landbouwers de bas zijn, niet teweeg breugen, dat de bevoorregting verminderd wordt. Het gezamenlijk cijfer door de landbouwers als zocklanig aan directe belastingen opgebragt, is dan ook gering, vooral 
in streken, waar hunne levenswijze zoo hoogst eenvoudig is, dat zij maar op de harde banken rijden, en dus geene paarden in gemengd gebruik aangeren; nog kort geleden kende ik voorbeelden van zeer welvarende pachtboeren, die ondanks den geringen census ten platten lande, niet eens kiezers waren voor de 'Tweeds. Kamer en de Provinciale staten.

Dat het de landbouwers over het algemeen wel gaat, is zeker niet te betwijifelen; zij gaan, ondanks de vrij wat hoogere pachten die thans betaald worden en (uitgezonderd misschien enkele deelen van ons vaderland, waar het grootere deel der gronden in het openbaar verpacht worlt), ook kunnen betaald worden, goed vooruit. Hunne leveuswijze loopt zeer uiteen; in sommige oorden merkt men den grootsten eenvoud, dikwijls zelfs schrielheid op, in andere juist tentoonspreiding van de grootste weelde, soms zelfs van rerkwisting. Waar dat laatste gepaard gaat met den verbouw van meer wisselvallige vruchten, zooals meekrap, koolzaad en tabak, kunnen die hoog opgeroerde verteringen wel eens gevaarlijk zijn. Over het algemeen echter mag men wel aannemen, dat de landbouwer zeer wel kan doen, wat hij doet. Van nabij bekend met vele landbouwers en de wijze waarop zij of hunne ouders, jaren zelfs voor mijne geboorte begonnen, heb ik de trapsgewijze vermeerdering der fortuinen kunnen nagaan. Velen humner zijn met uiterst weinig begonnen, en het was niet zeldzaam, dat het bedrijfkapitaal geheel werd opgenomen.

Warmoezerij, veeteelt en melkerij leveren zeker op den duur nog veel voordeeliger uitkomsten op dan de eigenlijk gezegde landbouw, doch ook dat bedrijf was, bij vele andere bedrijven vergeleken, nu reeds sedert vele jaren hoogst voordeelig.

Een talrijk gezin is dikwijls voor den stedeling, ook bij de meeste zuinigheirl eene reden van achteruitgang, de plattelands-bewoner is ook daarin van veel beter conditie en voor een landbouwer is een groot getal kinderen dikwjls een elemeut van rijkdom.

'Leer zeker gaat niet elk individu vooruit, maar de bewering geldt vau den stand in het algemeen. In enkele oorden rouleert het geld door bepaalde banden en is men in staat vrij naauweurig te bepalen, wat in eenige gemeenten jaarlijks wordt overgelegd. Daaromtrent zijn mij belangrijke bijzonderheden en cijfers bekend, niet vatbaar intusschen voor openbare mededeeling.

De voortdurende verhooging vau pacht- en koopprijzen getuigt ook voor toenemende welvart, en is de ondervinding van mijne ambtgenooten gelijk aan de mijne, zoo wordt er door de eigenlijk gezegde landbouwers minder geld op hypotheek opgenomen.

In het algemeen, zoo is mijne ondervinding ook als hypotheek- 
bewarder, heeft die stand thans minder dan vroeger behoefte aan het kapitaal van anrleren, en waar die behoefte zich doet gevoelen, is het crediet zeer tikwijls genoeg gevestign om het benoodigde los uit de hand, vaak van andere landbouwers to bekomen. Ik hel wol cens de zonderlinge bewering gehoord, dat eene belasting de wel. vaart zoude bevorderen, ik geloof echter lat wij nog verre verwijderd zijn van den tijd, dat men uit dat oogpunt naar helastingen zal wenschen; de verpligting cvenwel tot het voldoen van belastingen, kan de meuschen tot meerdere werkzaamheid en zuinigheid aansporeu, ook kan zij doen wenschen naar meer regelmatige verdiensten, en dat kan leiden tot eene voortdurende vergrooting van den veestapel, wat wederom een gumstigen invloed moet uitoefenen op de vruchtbaarheid van het land dat men blijft behouwen, en meerdere gelegenheid tot het in kultuur brengen van woeste gronden zal aanbieden.

De fiscus zorge steeds zooveel mogelijk zijn quota te heffen van de inkomsten, zoo weinig als dat maar kan van het kapitan 'en waar, bij het beramen van nieuwe middelen, een stoot kan gegeven worden, die de burgers noopt zich in eene goede rigting te bewegen, worde dat vooral niet verzuimd.

Gaf ik te kennen, dat er aan de zuivelbereiding meer regelmatige inkomsten verbonden zijn, blijft de prijs van dat artikel door den zoo belangrijken uitroer voortdurend gunstig, het is zeer te vreezen, wanneer de vervalsching stand houdt, zoo als wij diswijls uit de dagbladen veruemen, dat gezegd artikel, eveu als weleer de meekrap (ten aanzien waarvan toen nog maatregelen van toezigt beatonden, die echter weinig nut gedaan hebben) op de buitenlandscbe markt gedeprecieerd wordt.

Beschermende middelen zijn op den duur voor elken tak van nijverheid en voor ieder bedrijf af te keuren; kunnen zij bij de eerste wording van eene nijverheid, die anvankelijk met groote bezwaren en kosten te worstelen heeft, (doch alleen wauneer zij later goede uitkomsten ten nutte van het algemeen belooft, en slechts tijdelijk) hun nut hebben, een kunstmatig gevoed leven is nateelig voor het algemeen belang, ja op den duur voor den producent zelren, die, wanneer hij alleen op eigen kracht had moeten steunen, het dikwijls veel verder zonde hebben gebragt.

Welnu, bevoorregting in belastingzakeu is ook eene bescherıning en moet evenzeer worden afgekeurd, in gewone tijden althans; buitengewone omstandigheden toch, wanneer b. $v$. eene streek veel geleden heeft door oorlogsrampen, eischen buitengewoue voorzienjug.

Gelijk men in de natuur trapsgewijzen vooruitgang en ontwikkeling wanuoent, zoo moeten, om het algemeen geluk te vestigen en te be. 
stendigen, om de algemoene welvaart to bevorleren, of, wat den fiscns anngat, zoo weinig als mogelijk is te belemmeren, ook de staatsman en sta thuishoudkundige die natuurwet eerbiedigen. Zoo kunnen elementen van belasting, (indien ze althans niet bepaald verderfelijk zijn), wanncer zij jaren bestaan hebben, schoon men ze in het afgetrokkene beschouwd niet zonde invoeren, behouden blijven, mits anngevuld of gewijzigd wordencle.

Zoo moet ook de bevoorregting die men opmerkt, niet op eens maar voorzigtig en trapsgewijze worden opgeheven. Ieder vo!k is gevoelig in de beurs, de geschiedenis leert ons, dat de Nederlander het niet het minst is, en de landbouwer is Nederlander. De verpligting om eeve schrede terug te moeten gaan, is steeds uiterst gevaarlijk, het is daarom zeer te wenschen, dat men bij het vaststellen van bet verhoogd quota door de landbouwers te betalen in aanmerking neme de hooge pachten, bij middelmatige oogsten en lage prijzen.

In het bovenstaande lieb ik kortelijk op een bestaande leemte in ons belastingstelsel willen verwijzen, - ecn leemte trouwens die vrij alge. meen erkend wordt. Men beschouwe het meer als eene herinnering aan het belang van het onderwerp, nu dat weder aan de orde is gekomen.

Heb ik in dit kort betoog ook al getracht de meeste billijkheid in acht te nemen, ik betwijfel het echter geenzins, dat die beschouwingen bij onze landbouwers slechts weinig populariteit zullen verwerven. Dat is dan ook geenszins het doel van mijn schrijven. Amicus Plato, magis amica verilas.

Gorinchem, 1 Julij 1863.

A. VAN ECK.

NASCHRIFT DER REDACTIE. Scloon wij het met $\mathbf{S}$. betoog in strekking eens zijn, kumen wij het toch niet in alle bijzonderheden toegeven, bepaaldelijk niet wat de grondbelasting betreft. Wel is het uiterst bezwaarlijk, juist aan te toonen door wie de belasting gedragen wordt, daar de overdragten van grond en verpachtingen zich over reeksen van jaren en ongelijke tijdstippen verdeelen, - doch het is toch moeijelijk vol te houden, dat alleen de koopers en pachters de goede fnanciers zouden ziju die bunne prijzen zoo regelen dat zij bet verlies allcen door de rerkoopers doen dragen. Ook deze kennen en zoeken hun belang, en zullen dus evenzeer bunne war op prijs houden en speculeren op den lust van koopers en grondeigenaars, en op de lust, ja de noodzakelijhlieid van pachters om bebouwers te worden of te blijven. - Men vergeet soms dat de grondbelasting zoo volstrekt algemeen op elken grond in het geheele rijle drukt, en dat, zoo alle vragers naar grond de verhongde lasten bij hun koopprijs in rekening nemen, en de pachters slechts zien op de waarde aan producten die zij uit den grond kunnen krijgen, erenzeer al de aaubieders van grond trachten er zonder verlies af te komen. - Zij die gedrongen zijn le verkoopen, zij die in geldnood zitten zijn dan natuurlijk in de slechtste conditie, maar evenzeer zal van de slechtste conditie zijn hij die gedwongen is te huren, en is Let niet natuurlijk aan te nemen dat op den duur een gedeelte vau de belasting wel door nieuwe verkrijgers en pachters zal gedragen worden? (Wij verwịzen overigens naar Beg. van staath. 3 e druk. hoofdstuti: belustingen.)

Low. 1863. 
UITVOER VAN JAVA A0 1858-A0 1862. *)

\begin{tabular}{|c|c|c|c|c|c|c|c|c|c|c|c|c|c|}
\hline \multirow[b]{2}{*}{ GOEDEREN. } & \multirow[b]{2}{*}{ Jaren. } & \multicolumn{2}{|c|}{$\begin{array}{c}\text { Naar Nederinnd } \\
\text { door: }\end{array}$} & \multirow{2}{*}{ 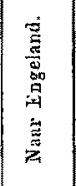 } & \multirow{2}{*}{ 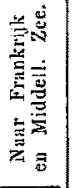 } & \multirow{2}{*}{ 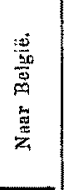 } & \multirow{2}{*}{ 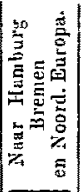 } & \multirow{2}{*}{ 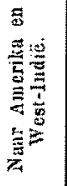 } & \multirow{2}{*}{ 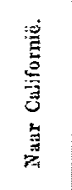 } & \multirow{2}{*}{ 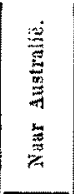 } & \multirow{2}{*}{ 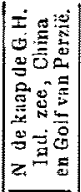 } & \multirow{2}{*}{ 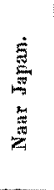 } & \multirow[b]{2}{*}{ Torrat. } \\
\hline & & 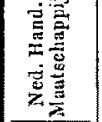 & 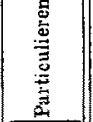 & & & & & & & & & & \\
\hline \multirow[t]{5}{*}{ Kofflj $\cdot p^{\text {ikools }}$} & 1858 & 994690 & 74753 & - & 65218 & - & 5371 & 8322 & 4579 & 4329 & 2186 & - & 1159445 \\
\hline & 1859 & y 13039 & 31568 & 2 & 58310 & - & 179 & (6)15 & 3191 & 3253 & 1814 & - & $101817 t$ \\
\hline & 1860 & $84+533$ & 81990 & 2 & 40912 & - & 984 & 10 & -2795 & 229 & 830 & - & 972346 \\
\hline & 1861 & 811240 & 85585 & 638 & 33507 & - & 100 & 2012 & - & 5117 & 982 & - & $9: 39181$ \\
\hline & 1862 & 877241 & 128047 & - & 39153 & - & 293 & 64 & 412 & 1531 & 305 & - & 104235 \\
\hline Suiker. pikols & 1858 & 1007093 & 773680 & 50931 & 50170 & 18410 & 58521 & 3541 & 4378 & $128 \pi 7$ & 51128 & - & 2040052 \\
\hline & 1859 & 1027140 & 930169 & 19485 & 25027 & - & 30789 & 14490 & 3528 & 76909 & 39955 & - & $21+6190$ \\
\hline & 1860 & 770003 & $05+871$ & 51715 & 50357 & - & 22578 & 41704 & 3471 & 25004 & 44418 & - & 1964124 \\
\hline & 1961 & 831560 & $89624:$ & $|1+3 \pi 2 \pi|$ & 21833 & - & 1.6100 & $96 \pm 8$ & - & $66 a 17$ & 51822 & -- & 2437258 \\
\hline & 1862 & $93 \% 5 \overline{4}$ & 1138367 & 25168 & 34149 & - & $1+237$ & 1833 & -1 & 105444 & 71271 & - & 2336000 \\
\hline Rijst . : pikols & 1858 & - & 252280 & 27925 & 9740 & - & 19445 & 4540 & 12597 & 20015 & 678911 & - & $919+2$ \\
\hline 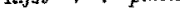 & 1859 & - & 559219 & 62010 & 3775 & - & 38798 & 16140 & $3 \div 93$ & $7+45$ & $2 \mathrm{~s} 2032$ & - & 992742 \\
\hline & 3860 & 2001 & 226091 & 581.23 & 822 & - & 50973 & 4131 & 11311 & $1+181$ & $\tilde{5} 12015$ & - & $8790+8$ \\
\hline & 1861 & $24+1$ & 201872 & 24663 & 5045 & - & 4580 & 11701 & & 13031 & 214122 & -1 & $47804 j$ \\
\hline & 1862 & - & 133523 & 41553 & - & - & +362 & 6000 & 4160 & 18072 & 262221 & - & 469891 \\
\hline Arak . leggers & 1858 & - & 5634 & 220 & 1 & - & 685 & - & 10 & 60 & 650 & 3 & 7260 \\
\hline & 1859 & - & 5329 & - & - & - & 604 & 13 & - & 62 & 417 & -1 & 6423 \\
\hline & 1860 & - & 2884 & 452 & - & - & 318 & 874 & 53 & 89 & 422 & - & 5088 \\
\hline & 1861 & - & 5728 & 180 & - & - & 23 & - & - & 28 & 139 & - & 6098 \\
\hline & 1862 & - & 3518 & - & - & - & 250 & - & 18 & 3 & 1285 & 2 & 3052 \\
\hline Rotting - pikols & 1858 & 26370 & $2+353$ & 1602 & 5189 & 415 & 1862 & 19700 & 95 & 342 & 36746 & 510 & 1173813 \\
\hline & 1859 & 30170 & 20512 & 3325 & 3380 & -1 & 8678 & 11963 & 70 & 630 & 3545 & - & 91354 \\
\hline & 1860 & 19706 & 20022 & 1222 & 2403 & - & 504 & 5386 & 267 & 1536 & 5730 & - & GESA \\
\hline & 1861 & 20801 & 17872 & 2310 & 1638 & - & 377 & 835 & - & 1127 & 7952 & - & 59912 \\
\hline & 1862 & 21870 & 19379 & 001 & 1126 & - & 190 & 488 & 82 & 1007 & 4663 & 600 & 50156 \\
\hline Peper. pikols & 1858 & 4486 & $176 川$ & 542 & 5361 & - & 250 & 154 & 290 & 590 & 957 & - & $1+320$ \\
\hline & 1859 & 2937 & 3485 & 147 & 2893 & - & - & 109 & 22 & 777 & 1354 & - & $162 \pi$ \\
\hline & 1860 & 7031 & 2003 & 2710 & 258 & - & 34 & -1 & 10 & 798 & 411 & -3 & 145 \\
\hline & 1861 & 4901 & $+20+$ & 1688 & 1815 & - & - & 374 & -1 & 863 & 458 & -1 & $1+ \pm 09$ \\
\hline & 1862 & 1615 & 6171 & 422 & 722 & - & 4 & 558 & 173 & 1165 & 498 & - & $11 \beta^{328}$ \\
\hline Gom-elastiek pikols & 1858 & - & 3113 & 183 & 616 & - & 34 & 1603 & - & - & 779 & - & 6330 \\
\hline & 1850 & - & 2471 & $12+1$ & 890 & $=$ & 387 & 1618 & - & $\ldots$ & 461 & - & 7006 \\
\hline & 1860 & - & 9390 & 2268 & 1952 & - & 50 & 1356 & - & - & 1034 & -1 & $160 \% 5$ \\
\hline & 1861 & 100 & 1021 이 & 301 & 60 & -1 & 700 & - & - & - & 500 & - & 11949 \\
\hline & 1862 & - & 3990 & 364 & 167 & $-\infty$ & 112 & - & - & - & 1123 & - & 7696 \\
\hline Huiden. siuks & 1858 & 18790 & 181886 & 4725 & 15769 & - & 2208 & $\ldots$ & - & 205 & 5190 & 208 & 231971 \\
\hline & 1859 & \$) 13500 & 115871 & 68.5 & 19985 & - & 505 & 5817 & - & - & 3430 & - & $16 ; ; 963$ \\
\hline & 1860 & & 102107 & 6782 & 6303 & - & 15001 & - & 550 & 750 & 6539 & - & 138092 \\
\hline & 186 & 2000 & 145802 & 9600 & & - & 6400 & - & - & - & 3282 & - & 1 thiost \\
\hline & 1862 & 6500 & 209100 & 1567 & 11600 & - & 40 & - & - & - & 8852 & - & $296 \%$ \\
\hline Tabak , pikols & 1853 & 673 & 71830 & - & - & - & 80 & 51 & - & - & - & - & 72784 \\
\hline & 1859 & - & $5227 \pm$ & - & - & - & - & 70 & - & - & 71 & - & 52415 \\
\hline & 1860 & - & 65793 & - & - & - & 14 & 29 & 一 & 50 & 220 & - & 66100 \\
\hline & 186 & 5 & $8119 \bar{\tau}$ & - & - & - & - & - & - & - & $32 \frac{1}{2}$ & - & 81164 \\
\hline & 1862 & $382 \mathrm{~L}$ & $98011\}$ & - & -1 & - & - & -1 & - & 30 & 7540 & - & $10940 \%$ \\
\hline Indigo,$+p^{\text {pand }}$ & 1858 & $56 \pm 625$ & 323110 & 345 & 61781 & - & - & $10 \vec{v}$ & - & - & 2856 & 10 & $35+12 ?$ \\
\hline & 1859 & †) 852500 & 440918 & - & 40010 & - & - & - & - & - & 476 & - & 193,904 \\
\hline & 1860 & 673750 & $330 \pm 15$ & 250 & $22+17$ & - & - & 3154 & - & - & 22594 & - & $10 \div 2580$ \\
\hline & 1861 & 487750 & 281741 & - & 21677 & - & - & - & - & - & - & - & 791168 \\
\hline & 1862 & 522000 & 317278 & - & - & - & 298 & - & - & - & 375 & $-\cdots$ & 839951 \\
\hline Nootmuskant pikols & 1858 & 6189 & 304 & 4 & - & - & 14 & 71 & - & 30 & 19 & - & 6631 \\
\hline & 1859 & 6774 & $17 \mathrm{~g}$ & 112 & 一 & - & 18 & 99 & 一 & 144 & 0 & - & 6334 \\
\hline & 1860 & 6621 & 317 & 92 & - & - & 21 & 91 & - & 138 & 31 & - & 6911 \\
\hline & 1861 & 9500 & 168 & 52 & - & - & 37 & - & -7 & 81 & $86 \mathrm{~L}$ & - & 9802 \\
\hline & 1862 & 63631 & 1111 & 11 & -1 & & 1 & & 38 & $92 \frac{1}{2}$ & 19 & & 6635 \\
\hline
\end{tabular}

*) Zie roor de jaren $1856-1657$ de tabel Economist 1801 , pag 249 .

6) Dit bedrag is calculatif, zijude de uitvoer der Ned. Hand. Maats, van Huilen sedert 1859 opgegeven in pilolg

†) De uitroeren van Indigo en Cochenille der Ned. Hand. Marts, in pikols opgegeven, zijn 125 pond per yikol in Amsterdamsche ponden gereduceerd. 


\begin{tabular}{|c|c|c|c|c|c|c|c|c|c|c|c|c|c|}
\hline COFTHREN. & Haren. & 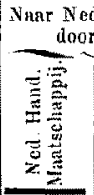 & rland & 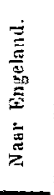 & 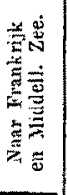 & 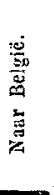 & 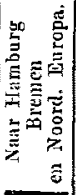 & 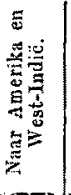 & 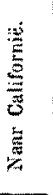 & 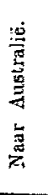 & 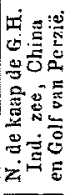 & 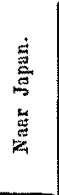 & Torante \\
\hline Fnelie . pizals & $\begin{array}{l}1558 \\
1679 \\
1860 \\
1661 \\
1.502\end{array}$ & $\begin{array}{l}1680 \\
1889 \\
1588 \\
250 \% \\
1700\end{array}$ & $\begin{array}{r}120 \\
47 \\
15 \\
20 \\
32\end{array}$ & $\begin{array}{r}6 \\
310 \\
5 \\
15 \\
3\end{array}$ & $\begin{array}{l}\bar{z} \\
\overline{-} \\
-\end{array}$ & $=$ & $\begin{array}{r}10 \\
2 \\
22 \\
1 \\
1\end{array}$ & $\begin{array}{r}6 \\
20 \\
- \\
- \\
-\end{array}$ & $\frac{-}{3}$ & $\begin{array}{r}\overrightarrow{18} \\
\frac{15}{12}\end{array}$ & $\begin{array}{r}15 \\
4 \\
11 \\
9 . \\
-\end{array}$ & $\begin{array}{l}\overline{1} \\
- \\
- \\
-\end{array}$ & $\begin{array}{l}1793 \\
2006 \\
1650 \\
2505 \\
1848\end{array}$ \\
\hline Timeel. pithols & $\begin{array}{l}1858 \\
1869 \\
1860 \\
1561 \\
1862\end{array}$ & $\begin{array}{r}2160 \\
1890 \\
2042 \\
1755 \\
680\end{array}$ & $\begin{array}{r}4.2 \\
1+5 \\
41 \\
163 \\
\end{array}$ & $\begin{array}{l}- \\
-7 \\
34 \\
2 \\
-\end{array}$ & $\begin{array}{l}- \\
- \\
- \\
-\end{array}$ & $=$ & $\begin{array}{r}- \\
39 \\
114 \\
28 \\
-\end{array}$ & $\begin{array}{l}= \\
=\end{array}$ & $=$ & $\bar{z}$ & $\frac{z}{\frac{1}{2}}$ & $\begin{array}{l}= \\
= \\
-\end{array}$ & $\begin{array}{r}2202 \\
2058 \\
2231 \\
1802 \\
680\end{array}$ \\
\hline Culichen a pikots & $\begin{array}{l}1859 \\
1850 \\
1860 \\
1861 \\
1862\end{array}$ & $=$ & $\begin{array}{r}202 \\
55 \\
2115 \\
1100 \\
598\end{array}$ & $\begin{array}{r}\bar{z} \\
\overline{11 \overline{3}} \\
\overline{3 i}\end{array}$ & $\begin{array}{l}79 \\
135 \\
1015 \\
3192 \\
306\end{array}$ & $=$ & $\begin{array}{l}- \\
13 \\
52 \\
27 \\
21\end{array}$ & $\begin{array}{l}45 \\
99 \\
48 \\
- \\
-\end{array}$ & $\bar{z}$ & $\begin{array}{l}\bar{Z} \\
\overline{17 \pi}\end{array}$ & $\begin{array}{r}88 \\
88 \\
67 \\
393\end{array}$ & $\begin{array}{l}\bar{z} \\
\bar{z}\end{array}$ & $\begin{array}{r}n 84 \\
388 \\
2505 \\
1486 \\
1347\end{array}$ \\
\hline Samonhout pilots & $\begin{array}{l}1858 \\
1859 \\
1860 \\
1861 \\
1862\end{array}$ & $\begin{array}{l}- \\
- \\
-\end{array}$ & \begin{tabular}{r|}
2625 \\
$1+25$ \\
450 \\
$3+05$ \\
3354
\end{tabular} & $\begin{array}{r}300 \\
+54 \\
1058 \\
900 \\
990\end{array}$ & $\begin{array}{c}319 \\
86 \\
- \\
-\end{array}$ & $=$ & $\begin{array}{c}8033 \\
-752 \\
780 \\
-\end{array}$ & $\begin{array}{r}\bar{z} \\
\overline{100}\end{array}$ & $=$ & $\frac{\bar{Z}}{840}$ & $\begin{array}{r}506 \\
2204 \\
80 \\
745\end{array}$ & $\begin{array}{r}7391 \\
4058 \\
- \\
-\end{array}$ & $\begin{array}{r}12553 \\
8225 \\
2020 \\
5925 \\
4372\end{array}$ \\
\hline Casin - pikots & $\begin{array}{l}1858 \\
1939 \\
1860 \\
1861 \\
1862\end{array}$ & $\begin{array}{r}- \\
- \\
157 \\
1448\end{array}$ & $\begin{array}{r}3+0 \\
1001 \\
1310 \\
860\end{array}$ & $\begin{array}{l}\ldots \\
130 \\
100 \\
-\end{array}$ & $\begin{array}{l}- \\
- \\
- \\
-\end{array}$ & $=$ & $\begin{array}{c}- \\
\overline{51} \\
100 \\
-\end{array}$ & $\begin{array}{c}400 \\
= \\
=\end{array}$ & $=$ & $\begin{array}{l}- \\
\overline{15} \\
-\end{array}$ & $\begin{array}{c}30 \\
- \\
- \\
318\end{array}$ & $\begin{array}{l}- \\
- \\
-\end{array}$ & $\begin{array}{r}970 \\
1190 \\
1868 \\
2631\end{array}$ \\
\hline Gom dammal pikols & $\begin{array}{l}1858 \\
1859 \\
1860 \\
1861 \\
1862\end{array}$ & $\frac{-}{932}$ & $\begin{array}{l}4006 \\
3209 \\
3065 \\
30+9 \\
1107\end{array}$ & $\begin{array}{l}208 \\
608 \\
921 \\
511 \\
276\end{array}$ & $\begin{array}{l}949 \\
668 \\
187 \\
864\end{array}$ & $=$ & $\begin{array}{c}390 \\
- \\
719 \\
445\end{array}$ & $\begin{array}{c}130 \\
200 \\
200 \\
- \\
-\end{array}$ & $=$ & $\begin{array}{r}8 \\
22 \\
- \\
-\end{array}$ & $\begin{array}{r}421 \\
192 \\
387 \\
-\end{array}$ & $\begin{array}{l}- \\
25 \\
- \\
-\end{array}$ & $\begin{array}{l}6104 \\
5265 \\
4605 \\
4966 \\
6624\end{array}$ \\
\hline Guttaperchil pikols & $\begin{array}{l}1858 \\
1859 \\
1860 \\
1861 \\
1862\end{array}$ & $\begin{array}{l}- \\
- \\
4 \\
28\end{array}$ & $\begin{array}{l}258 \\
2 \pm 3 \\
181 \\
261 \\
194\end{array}$ & $\begin{array}{l}- \\
\frac{-}{12} \\
-\end{array}$ & $\begin{array}{l}- \\
12 \\
-\end{array}$ & $=$ & $\begin{array}{l}- \\
- \\
-\end{array}$ & $\begin{array}{l}-\overline{8} \\
- \\
-\end{array}$ & $=$ & $\begin{array}{l}= \\
= \\
=\end{array}$ & $\begin{array}{l}\frac{-}{66} \\
- \\
86\end{array}$ & $=$ & $\begin{array}{l}258 \\
316 \\
198 \\
277 \\
308\end{array}$ \\
\hline Cochenille = pout & $\begin{array}{l}1858 \\
1879 \\
1860 \\
1802 \\
1862\end{array}$ & *) $\begin{array}{r}54373 \\
40875 \\
18750 \\
40875 \\
26250\end{array}$ & $\begin{array}{r}29394 \\
1451 \\
2305 \\
1260 \\
198\end{array}$ & $\begin{array}{l}- \\
- \\
-\end{array}$ & $\begin{array}{r}1100 \\
= \\
= \\
\end{array}$ & $=$ & $\begin{array}{l}5 \\
= \\
=\end{array}$ & $\begin{array}{l}= \\
= \\
=\end{array}$ & $=$ & $\begin{array}{l}- \\
= \\
=\end{array}$ & $\begin{array}{l}\frac{62}{20} \\
- \\
-\end{array}$ & $\begin{array}{r}1190 \\
= \\
=\end{array}$ & $\begin{array}{l}86121 \\
42826 \\
21075 \\
42135 \\
26448\end{array}$ \\
\hline Tisee . pikols & $\begin{array}{l}1858 \\
18600 \\
1800 \\
1861 \\
1800\end{array}$ & $\begin{array}{l}15853 \\
15258 \\
17048 \\
15678 \\
13045\end{array}$ & $\begin{array}{r}1.93 \\
59 \\
238 \\
663 \\
22940 \\
20\end{array}$ & $\begin{array}{l}- \\
\overline{9} \\
-\end{array}$ & $\begin{array}{l}- \\
2 \\
-\end{array}$ & $\begin{array}{l}30 \\
- \\
-\end{array}$ & $\begin{array}{r}- \\
3 \\
56 \\
- \\
-\end{array}$ & $\begin{array}{l}= \\
\overline{-} \\
-\end{array}$ & $=$ & $\begin{array}{l}\frac{-}{35} \\
\frac{-}{24} \\
-\end{array}$ & $\begin{array}{l}- \\
- \\
-\end{array}$ & $\begin{array}{l}- \\
- \\
- \\
-\end{array}$ & $\begin{array}{l}16061 \\
18857 \\
17332 \\
19363 \\
15785\end{array}$ \\
\hline Tiil . . pitiols & $\begin{array}{l}1858 \\
1859 \\
1860 \\
18011 \\
1882\end{array}$ & $\begin{array}{l}7+337 \\
81950 \\
78557 \\
72182 \\
63274\end{array}$ & $\begin{array}{r}2200 \\
2957 \\
4580 \\
261 \\
950\end{array}$ & $\begin{array}{l}- \\
- \\
-\end{array}$ & $\begin{array}{r}- \\
34 \\
503 \\
518\end{array}$ & $=$ & $\begin{array}{l}= \\
= \\
=\end{array}$ & $\frac{-}{630}$ & $\begin{array}{l}- \\
m \\
-\end{array}$ & $\begin{array}{l}- \\
- \\
- \\
-\end{array}$ & $\begin{array}{r}51 \\
160 \\
20 \\
- \\
-\end{array}$ & $\begin{array}{l}68 \\
- \\
-\end{array}$ & $\begin{array}{l}70656 \\
85771 \\
83510 \\
75308 \\
64750\end{array}$ \\
\hline
\end{tabular}

*) De uitroeren van 1ndigo en Cochenille der Ned. Hand. Maats., in pikols opgegeven, zijn a 125 pond per pikol in dusterdamscle ponden gereduceerd. 
Ten gevolge van onvolledigheid in de opgaven ontrent den invoer moeten wij ous gewone overzigt van den Java-handel (Economist 1861 pag. 238) voor dezen keer beperken tot den voorafgaauden vergelijkenden staat van eenige voorname artikelen van uitroer.

Daarnit blijkt dat de koffij uitroer in 1861 zijn laagste standpunt bereikt heeft, en in 1862 weder het gemiddelde cijfer van ruim één millioen picols aangeeft. De particuliere uitvoer afzonderlijk beschouwd, geeft de volgende uitkomst:

\begin{tabular}{|c|c|c|c|c|c|c|c|c|}
\hline & & $\ln d u$ & izend & tallen & $\operatorname{van}$ & Pico & & \\
\hline & & 1856 & 1857 & 1858 & 1859 & 1860 & 1861 & 1862 \\
\hline naar & Nederland & 12 & 17 & 75 & 32 & 82 & 85 & 128 \\
\hline$"$ & Frankrijk ... & 50 & 41 & 65 & 58 & 41 & 34 & 30 \\
\hline$"$ & $\begin{array}{l}\text { Overig Europa } \\
\text { En Amerika }\end{array}$ & 21 & 5 & 18 & 10 & 4 & 3 & 5 \\
\hline$"$ & A ustralië en Indië & 2 & 5 & 7 & 5 & 1 & 6 & 2 \\
\hline & Totaal. & 85 & 68 & 165 & 105 & 128 & 128 & 165 \\
\hline
\end{tabular}

De vermeerdering van den particulieren uitroer is gedeeltelijk toe te schrijpen aan de veilingen van gouvernements-koffij op Java, die in 1862 bestonden uit 25000 picols, geveild in September en grootendeels voorko. mende onder den uitvoer van dat jaar, en 25000 picols geveild in December, welke eerst op de staten van het loopende jaar onder den uitvoer zullen worden opgenomen.

De suiker-uitvoer was in de beide laatste jaren weder klimmende, en in 1862 is de toename vooral van den uitvoer door particulieren zoo belangrijk dat het hoogste eijfer van de tabel wordt bereikt, Nederlands andeel in die exportatie bleef aanzienlijk; doch het is te betreuren, dat de vermeerdering van het aantal picols slechts is verkregen ten koste van $\mathrm{kwaliteit,}$ daar er in de laatste jaren meer dan imner slappe en vochtige suiker is ingevoerd, en dat de uitvoer naar Nederland in den regel verlies in plaats van winst heeft opgeleverd.

De particuliere uitvoer verdeelt zich als volgt:

\begin{tabular}{|c|c|c|c|c|c|c|c|c|c|}
\hline & & & 1856 & 1857 & 1858 & 1859 & 1860 & 1861 & 1862 \\
\hline naar & Nederland & & 389 & 478 & 774 & 930 & 955 & 896 & 1138 \\
\hline$"$ & Engeland & & 9 & 30 & 50 & 19 & 52 & 144 & 25 \\
\hline$"$ & Frankrijk & & 28 & 143 & 60 & 26 & 50 & 22 & 34 \\
\hline " & Overig Europ & & 127 & 88 & 77 & 31 & 23 & 16 & 14 \\
\hline$"$ & Amerika . & & 22 & 26 & 8 & 18 & 45 & 10 & 2 \\
\hline$n$ & Australië. . & . . . & 23 & 27 & 13 & 75 & 25 & 66 & 100 \\
\hline " & Indië Golf $v$. & Persiën & 21 & 19 & 51 & 40 & 44 & 52 & 71 \\
\hline
\end{tabular}

Total . . . $619 \quad 8111033113911941206 \quad 1390$ mill. picols.

De hooge rijstprijzen die op Java beerschende bleven deden den uitvoer verder verminderen, de verzendingen naar Nederland bedrnegen in 1862 niet bet vierde deel van het cijfer van 1856 of van 1859 .

De vitvoer van Arak blijft tusschen 5000 en 6000 leggers op en neder gaan: 1862 kenmerkte zich door, het laagste eijfer vau uitroer, en de prijzen zijn daardoor belangrijk gerezen. 
Van Bindrotting was de uitvoer afnemende, hetwelk nitsluitend moet worden toegeschreven an gebrek aan disponibele waar, aangezien de prijzen op Java en in Nederland hoog blijven.

De uitvoer van Peper oscilleert de laatste zes jaren tussehen 11000 en 14000 picols, en het afgeloopen jaar geeft ook voor dit artikel het laagste cijfer.

Van gom-elastiek komt niet genoeg aan de markt om den belangrijken uitvoer van 1860 vol te houden, en het cijfer vau 16000 picols liep achtereenvolgens tot 12000 in 1861 , en 7700 in 1862 terug. Van guttapercha werd iets meer uitgevoerd.

In Euiden was de uitvoer onder den invloed van boogere prijzen in Europa in 1861 en 1862 belangrijk toenemende.

Hetzelfde geldt in nog ruimer mate van Tabak, waarvan in 1862 ruim 109000 picols werden uitgevoerd, grootendeels naar Nederland, zoodat dit artikel thans eene voorname plaats inneemt in het verkeer tusschen kolonie en moederland.

De vermindering van de Indigo-cultuur doet zich gaandeweg in den uitvoer gevoelen. Wel is waar geeft 1862 uog iets hooger cijfer dan zijn voorganger, doch dit neemt niet weg dat de algemeene strekking die van trapswijze vermindering is.

Omtrent de overige artikelen is weinig belangrijks te observeeren. Kaneel en Tin toonen in 1862 een vrij groot défécit, gom-damar en cassia daarentegen eene toename in den uitvoer.

De uitvoer van producten naar Engeland was in de twee laatste jaren over bet. geheel afnemende, indien men de belangrijke suiker-exportatie in 1861 uitzondert.

Frankrijk, Hamburg, Noordelijk Europa trokken in de twee laatste jaren veel minder producten dan voorheen.

Ook Amerika's aandeel was gering, waarschijnlijk ten gevolge van den burgerkrijg in de Vereenigde Staten.

Daarentegen is eene belangrijke toename te bespeuren in het verkeer met Australië en vooral in de Suiker-exportatie derwarts.

Amsterdak.

J. B. 